Journal of Social Sciences (COES\&RJ-JSS)

ISSN (E): 2305-9249 ISSN (P): 2305-9494

Publisher: Centre of Excellence for Scientific \& Research Journalism, COES\&RJ LLC

Online Publication Date: $1^{\text {st }}$ January 2019

Online Issue: Volume 8, Number 1, January 2019

https://doi.org/10.25255/jss.2019.8.1.7.23

\title{
Reviewing the Mediating Role of Job Satisfaction on the Effect of Employee Engagement on Organizational Performance
}

\author{
Rana Khaled Abu Khalaf \\ Department of Business Management, School of Business, The University of Jordan, \\ Amman, Jordan, rana_abukhalaf@yahoo.com

\section{Hazar Y.Hmoud} \\ Department of Management Information Systems, School of Business, The University of \\ Jordan, Amman, Jordan, h.hmoud@ju.edu.jo \\ Bader Obeidat \\ Department of Business Management, School of Business, The University of Jordan, \\ Amman, Jordan, b.obeidat@ju.edu.jo

\begin{abstract}
:
Businesses are trying to flourish and adapt to the various challenges they encounter in today's competitive environment by improving their organizational performance. In order to achieve better results and higher profit margins organizations are adopting various emerging business tools and management philosophies. Business performance relates to the achievement of a firm's strategic objectives and growth goals. Both financial and non-financial measures should be used to enable a firm to make efficient strategic decisions and to measure long term success. The purpose of this paper is to reviewing the literature regarding the mediating role of job satisfaction on the impact of employee engagement on organizational performance.
\end{abstract}

Keywords:

Employee engagement, job satisfaction, organizational performance

\section{Citation:}

Khalaf, Rana Khaled; Hmoud Hazar Y.; Obeidat, Bader (2019); Reviewing the Mediating Role of Job Satisfaction on the Effect of Employee Engagement on Organizational Performance; Journal of Social Sciences (COES\&RJ-JSS), Vol.8, No.1, pp:7-23; https://doi.org/10.25255/jss.2019.8.1.7.23. 


\section{Introduction}

Many companies realized that employees are organizations best assets that they can compete with internal and external organizations in their sectors (Bailey et al., 2016). In today's business world, employees' requirements go beyond the basic salary, which has shifted the focus of employers to understand the true essence of the employee engagement practices. Employees, in the present context, expect to be engaged in the organizational working, that is, their role should contribute and affect the business in a greater sense (Deeb et al., 2019). Employee engagement and employee-organizational commitments are critical organizational requirements as organizations face globalization, competitors and innovative individuals and others, specially recovering from the global recession to gain competitive advantage over the others (Anitha, 2014). Employee engagement and job satisfaction are regarded as interchangeable concepts; however; it is not necessary that a happy employee is always a healthy employee (Musgrove et al., 2014). Many researchers in their studies support the relationship between organizational performance and employees' engagement, for example, Albdour and Altarawneh (2014). This literature review, therefore, focuses on understanding the concept of employee engagement, job satisfaction and organizational performance and the relationship among these concepts.

\section{Employee Engagement}

\subsection{Definition of Employee Engagement}

According to Macey and Schneider (2008)employee engagement is an organizational workplace approach that results in the correct conditions for every member of the organization for giving effective performance every day, being committed to the goals and values of the organization, and being motivated for contributing to organizational success. Others, such as Mone and London (2010) and Anitha (2014) stated that employee engagement refers to the positive behaviors as well as attitudes leading to enhanced organizational outcomes. According to Albdour and Altarawneh (2014), employee engagement is related to the employees' involvement and dedication towards their work and achieving the goals of the organization. Engagement is also defined as the way people incorporate their own finger print during the performance of their job, whether physically, cognitively, and emotionally (Bandura and Lyons, 2014).

Others defined engagement as an effective emotional statement; engaged employees have a high level of energy and mental resilience, willingness to invest effort in ones work, involvement in their work, feel pride and enthusiasm, are fully attached to their work, and are passionate about their duties (Karanika-Murray et al., 2015). Phillips (2014) stated that engagement is more than being satisfied with job, it is about being innovative, creation, and be able to take personal responsibility to make things happen and not just work within the job needs. Thus, employee engagement is defined in general as the level of commitment and involvement an employee has towards their organization and its values. The engagement of employee is an extent to which the employees of an organization feel passionate regarding their jobs (Anitha,2014), become committed to their organization as well as put their discretionary efforts into the work they are assigned within the organization (Albdour and Altarawneh, 2014). 
Engagement of employee helps organizations increase their productivity and achieve their goals as employees give their best performance in order to enhance organizational productivity as well as achieve their goals (Anitha, 2014; Amhalhal et. al 2015). The major elements of employee engagement are commitment, motivation, loyalty and trust (Macey and Schneider, 2008). Commitment refers to a degree or extent to which the employees associate them with their jobs, organizational objectives as well as their responsibilities. Engaged employees get fascinated by their job as well as committed to deal with all the challenges for attaining their goals (Amhalhal et al., 2015). On the other side, motivation acts as the major aspect for the employee to put all their efforts for taking their organization to a next level. Apart of this, another element is loyalty, which refers that the employees who are strongly engaged in their job present more loyalty for their organization. The last element is trust which refers that the employee engagement can easily be fostered while trust prevails within the organization from dual sides (Amhalhal et al., 2015).

\subsubsection{Dimensions of Employee Engagement}

As suggested by Hogan and Coote (2014), the measurement of employee engagement refers to the extent the employees are engaged with the organization. The measurement of engagement is a challenging task as it is potentially based on the perception of employees that is subjective. However, employee engagement can be typically measured with the use of employee engagement survey, which has been developed especially for this purpose. The surveys on employee engagement must be benchmarked and statistically validated against other organizations or companies if they are likely to provide some useful outcomes (Bandura and Lyons, 2014). Without such aspects, it becomes difficult for knowing that what is being measured and whether the results are valid or not (Hogan and Coote, 2014). According to the views of Crawford et al. (2014), engagement of employees within an organization can be measured accurately with the use of short surveys which contain few questions. However, these short surveys can provide only an indication of the aspect that whether the employees in the organization are engaged. With the help of short surveys, it is difficult to find out that why the employees are engaged. In order to attain a complete scenario of employee engagement, the survey must include the variety of questions, which cover the entire range of topics regarding the engagement of employees.

There are several dimensions of employee engagement which make productive organizations stand apart as well as determine their destiny. These dimensions are "what do employees get", what do employees give", "do the employees belong to the company" and "how can employees grow" as defined by Xu and Thomas (2011). According to $\mathrm{Xu}$ and Thomas, what do employees get refers to that the employee engagement highly depends on what they get in exchange for performing their job (Gruman and Saks (2011). It includes basic compensation, efficient working environment as well as benefits (Gruman and Saks, 2011). What do employees give relates to a twoway process, setting the clear expectations essentially play a vital role (Macey and Schneider (2008)? It helps the employees in understanding what exactly is expected by the organization from them. It includes describing their job-related responsibilities that they require to fulfill as well as tasks that they require to perform (Macey and Schneider, 
2008). Do the employees belong to the company refers to whether social association is a basic requirement for every individual?(Amhalhal et al., 2015).Even the employees prefer to stay with an organization that treats them as an integral part of them and not only the means of getting their job done. How can employees grow refers to continuous growth including salary hikes, promotions, rewards as well as recognition, which are highly essential tools for retaining employees in an organization (Macey and Schneider, 2008).In order to determine whether employees in an organization are considered engaged or not three facets are taken into consideration, which include vigor, dedication, and absorption (Ferreira and de Oliveira, 2014).

\subsubsection{Vigor}

Vigor is referred to as "high energy, resilience, a willingness to invest effort on the job, the ability not to be easily fatigued, and persistence when confronted with challenges" (Ariani, 2013, p.47). Vigor is about the presence of four factors: First, high energy levels. Second, mental resilience. Third, willingness to invest effort and finally, the persistence in the face of challenges. All these factors are required in order for an individual to show vigor while performing a certain job (Schaufeli et al, 2006).

\subsubsection{Dedication}

Dedication refers to "being strongly involve in one's work and experiencing a sense of significance, enthusiasm, inspiration, pride, and challenge" (Ariani, 2013, p. 702). According to Ferreira and de Oliveira (2014) dedication is all about the mental and emotional state that reflects a sense of significance, enthusiasm, inspiration, and pride on experience. A person cannot be labeled as dedicated without the presence of such factors.

\subsubsection{Absorption}

Absorption refers to "a pleasant state of being immersed in one's works experiencing time passing by quickly and being unable to detach from the job" (Ariani, 2013, p. 47). A person who is absorbed in his or her job is characterized by being fully concentrated in his or her job, does not feel time passing by while performing the job, and has difficulty detaching or removing his or her self from work (Schaufeli et al, 2006).

\subsection{Organization Performance}

\subsubsection{Definition of Organization Performance}

The concept of organizational performance has been around for many years and has seen many transformations over the years. In the 1950s organizational performance referred to the extent to which organizations fulfilled their objectives. In the 1960s and 1970s organizational performance was defined as the ability of an organization to exploit its environment for accessing and utilizing limited resources. In the 1980s and 1990s organizational performance was seen as the ability to accomplish goals (effectiveness) using minimum resources(efficiency) (Gavera et al., 2011). In the twenty first century many definitions of organizational performance have been reported. According to Griffin (2003), organizational performance refers to the ability of organizations to meet the needs of stakeholders and its own needs for survival. Carton (2004) suggested that organizational performance is based on the premise of using human, physical, and capital 
resources in order to achieve a shared purpose. Antony and Bhattacharyya (2010) defined organizational performance as "a measure of how well organizations are managed and the value of they deliver to customers and other stakeholders" (p.43). All in all the essence of performance is value creation. So as long as the value created by the use of various assets owned by the organization is greater than or equal the value expected by the use of these assets, the assets will continue to be made available to the organization thus ensuring the existence of the organization (Carton, 2004).

Most literature suggests that when it comes to organizational performance, researchers find it difficult to define, conceptualize, and measure this concept (Taghian et al., 2015). Regarding the definition of organizational performance each person tends to have a different conceptualization of performance in general and organizational performance in particular. From a process point of view, performance refers to the transformation of inputs into outputs to achieve specific outcomes. From an economic point of view, performance is the relation between effective costs, realized output, and achieved outcomes (Abu Jarad et al., 2010).Performance at the organizational level refers to efficiency, productivity, absenteeism rate, turn-over rate, and adaptability (Obeidat, 2016). Organizational performance is considered an important indicator for the existence and survival of any organization by achieving its objectives through superior performance and having a competitive advantage (Obeidat, 2016). Another definition of organizational performance refers to it as "the ability to acquire and process properly human, financial, and physical resources to achieve the goals of the organization" (Ramezan et al., 2013, p.191).

Organization performance might be defined as the extent to which the organized teams or group of people are successful in performing a particular function. The performance of an organization is said to be high when all the components and parts of the organization work together to produce results, which can be measured in the context of the value delivered to the customer (Masa'deh et al., 2018). From the various definitions proposed it can be concluded that organizational performance require many components include strategic objectives, business performance measures, allocation of processes and resources, structure of the organization, reward structures and company's values and principles.

\subsubsection{Dimensions of Organization Performance}

According to Darwish (2013), organizational performance comprises of primarily three aspects, which an organization aims at accomplishing, namely- financial performance, market performance of its products and services, and shareholder returns. The financial performance is concerned with the returns on assets and capital employed, profits and revenues earned by the company and other dimensions. The product and service market performance are concerned with the market share of the company and sales, and the shareholder return is concerned with the economic value added, and total return for the shareholders. Various methods can be used to measure organizational performance. However, the basic method for its measurement is the comparison of the actual and expected outcomes or results of the organization. 
Traditionally organizations measured their performance using financial measures; however these measures have been criticized as they encouraged short-term view, rewarded short-term or incorrect behavior, caused management frustration and resistance, lacked strategic focus and the ability to provide data about quality, and failed to provide information about customer requirements and the quality of competitors' performance (Shahin et al., 2014). Given the downfalls of focusing solely on financial measures organizations have moved to adopting other methods for measuring performance. Kaplan and Norton (2001) developed the balanced score card (BSC) as a method to measure performance. This method provides a comprehensive framework for managers that allow them to modify the strategies of their organizations into a set of performance criteria. Tsai and Yen (2008) suggested that organizational performance can be measured using social and innovative performance in addition to financial and market performance. Mitchell (2002) provided four dimensions for measuring organizational performance which include: relevance of the company to stakeholder needs, effectiveness of the company, the efficiency of the company, and the financial viability of the company. Lee (2008) provides another way for measuring organizational performance through stakeholder satisfaction, organizational communication, team collaboration, strategic performance, knowledge management, and organizational growth. Even though the process of measuring organizational performance is already considered to be complex, it is reported that it will likely become even more complex due to changing stakeholder expectations concerning an organization's economic, social and environmental responsibilities (Hubbard, 2009).

The performance of organizations is affected by internal and external factors. Internal factors are considered firm specific and include leadership style, organizational culture, job design, and human resource policies. External factors can be the same for all firms; these include market preferences and perceptions, country rules and regulations, and the economy of the country (Chien, 2004; Mirza and Javed, 2013).In this study the dimensions of financial and non-financial performance will be used to measure organizational performance based on the study conducted by Hernaus et al (2012).

\subsubsection{Financial Performance}

Organizational performance measurement has become an increasingly important matter in order for organizations to survive under the pressure of world class competition (Masa'deh et al., 2008; Obeidat, 2015, 2016). Thus financial performance is regarded as a direct indicator of a firm's financial condition from various perspectives (Shi and Yu, 2013). An example of financial measures includes economic values added, revenue growth, costs, profit margins, cash flow, and net operating income. These measures are considered to be more objective compared to non-financial measures which are more subjective in nature (Abu Jarad et al., 2010). Prieto and Revilla (2006) stated that numerous factors affect a firm's financial performance some of these factors are economic conditions, changing government regulations, technological developments, and changes in the cost of producing and delivering products or services. Despite its popularity, financial measures of performance are no longer considered adequate means for exercising management control as they encompass many weaknesses such as failing 
to convey strategies and priorities effectively within an organization (Hernaus et al., 2012).

\subsubsection{Non-Financial Performance}

By the 1980s it became clear that traditional financial measures of performance were no longer sufficient to manage organizations competing in demanding and competitive markets (Obeidat, 2016; Ramezan et al., 2013; Kotane, 2012). This implies that financial measures that emphasize short-term indicators such as profit, turnover, and cash flow are not suitable anymore for measuring organizational performance and as a result nonfinancial measures have increased in importance.

According to Masa'deh et al. (2018), non-financial performance measures focus on achieving long-term success and incorporates factors that lead to improved organizational and financial performance. These non-financial measures include internal business process efficiency, innovation, and organizational commitment (Abu Jarad et al., 2010). In addition, Kaplan and Norton (2001) suggested that non-financial performance measures help managers in various ways. They help them assess the changes that occur in their business environments, determine and evaluate progress towards organizational goals, and affirm achievement of performance.

\subsection{Job Satisfaction}

\subsubsection{Definition of Job Satisfaction}

Fu and Deshpande (2013) defined job satisfaction as "A pleasurable or positive emotional state resulting from the appraisal of one's job or job experience". In the perception of Wicker (2011), the concept of job satisfaction can be understood through various ways. It depends upon the nature of the organization and the attitudes of the employees. Job satisfaction may be regarded as the extent to which an employee is content with the job, which he/she is performing, and the various aspects and facets of the job, which motivates an employee to like or dislike his job, such as supervision or the nature of the work performed. The literature provides that while measuring the affinity of employees towards their job, it is necessary that the multidimensional psychological aspects of the employee and the job are also taken into account. In support of the above arguments, Aziri (2011) added to the context stating that there are primarily three forces that make a person decide whether he is satisfied at his job or not. These forces are environmental (organization environment), physiological and psychological forces. As per this definition, even though the job satisfaction is affected by a number of external factors, but it is something internal in the employees that affect the manner in which an employee feels for his job.

Ahmad et al. (2014) found that good compensation systems will increase the performance to high level and retain the employees in the organization for long time after examining the job satisfaction factors such as pay, work itself, promotion, supervision, and co-workers. Therefore, it is important to focus more on paying systems to achieve better human resources practitioners. 


\subsubsection{Dimensions of Job Satisfaction}

According to Haque et al. (2012), the dimensions of job satisfaction or the factors affecting it have been broadly classified into two, namely- personal factors and organizational factors. The personal factors such as age, gender, race, and religion have a great impact on the job satisfaction level of employees. If the organization where the individual is working offers equal opportunities to the employees irrespective of the personal factors, the job satisfaction level of such employees is high. Organizational factors include leadership, technology innovation, professional development, recruitment, retention and rotation policies, working environment, salary and the workload. The literature provides that absence of these factors in an organization often cause stress and burden for the employees, which directly has an impact on the job satisfaction of employees.

Lovering (2017) argued that the dimensions of job satisfaction could be understood in the light of Herzberg two-factor theory. This theory explains that there are two kinds of factors namely: hygiene factors and motivators. The literature states the presence of the hygiene factors is necessary for an organization, without which the employee will not be satisfied in the organization and will not be able to work properly, such as work environment, fair policies, and fair pay. Motivators, on the other hand, aim at using the individual talents and help them in being recognized in the organization. This, in turn, motivates them to work better and ensures job satisfaction.

\subsubsection{Intrinsic Job Satisfaction}

Refers to how people feel about the nature of the job itself (Spector, 1997). It is concerned with the nature and consequences of work. Herzberg (1966) suggested that intrinsic job satisfaction factors include achievement, recognition, responsibility, advancement, growth, and the work itself. Although their absence was not necessarily dissatisfying, when present, they could be a motivational force(Baylor, 2010).

\subsubsection{Extrinsic Job Satisfaction}

Refer to how people feel about aspects of the work situation that are external to the job tasks or work-itself (Spector, 1997). Extrinsic satisfaction is concerned with the context in which the job has to be done. Extrinsic job satisfaction factors include supervision, working conditions, co-workers, pay, policies and procedures, job security, status, and personal life (Herzberg, 1966). They are not necessarily satisfying, but their absence could cause dissatisfaction (Baylor, 2010).

3. Employee Engagement and Job Satisfaction Job satisfaction is the outcome of good employee engagement practices. This is due to the reason that good employee engagement practice facilitates a channel of communication between the organization and its members. Employees are free to present their ideas, views, and opinions to their employers and are aware of the fact that their ideas will be recognized. These practices not only motivate the employees to work better but also provide them with a sense of belongingness, which eventually results in increased job satisfaction level of employees (Dajani, 2015). 
Similarly, Shmailan (2016) also added-to the above argument by-indicating that the employee engagement practices in the workplace ensure that the employees are ready to implement their skills, and ready to work for their organization by adopting a flexible working approach. These practices create such a working environment for the employees wherein they can share their perceptions and feelings with their colleagues and employers and are dedicated to the organization (Shmailan, 2016). This work commitment further ensures organizational effectiveness and job satisfaction in the employees. According to (Al-dalahmeh et al., 2018) employee engagement is positively associated and related with job satisfaction and organizational performance and negatively related to turnover and burnout.

\section{Job Satisfaction and Organization Performance}

In the viewpoints of Bakotic (2016), job satisfaction has a direct impact on the commitment level of an individual in an organization along with absenteeism and employee turnover rate in an organization. It further affects the performance level of not only the employees but also of the organization as it affects the employees' willingness to solve problems, take responsibilities, and put efforts beyond their job description. When the employees are satisfied with the work; which they do, they are likely to enjoy the experience and have less stress level (Bakotić, 2016). Moreover, satisfied employees generally have a positive outlook regarding their surroundings and a carefree perception about the work, which they also spread among their colleagues. This positive approach in the organization is responsible for improving the employees' performance and of the overall organization.

Latif et al. (2013) supported the above arguments by stating that increased job satisfactions make the employees productive by instilling the sense of commitment among them, which motivates them to work better for the success of the organization. This commitment further ensures that the employee turnover ratio of the company is less and the talent within the organization is used to the maximum extent (Latif et al., 2013). When employees are willing to take responsibilities and solve organizational problems, the performance of the employees and the entire organization can be improved.

\section{Employee Engagement and Organizational Performance}

According to Bakker and Schaufeli (2008), good employee engagement practices create a favorable working environment for the employees by providing them with various opportunities of sharing their ideas, suggestions and development opportunities. These practices have a positive influence on the employees and motivate them to give their maximum efforts in the organizational success and thereby enhance the organizational performance (Bakker and Schaufeli, 2008).

Rich, et al. (2010), on the other hand, stated that as the employee engagement practices affect the satisfaction level of employees, it is apparent that it indirectly contributes to the improved organizational performance. The engaged employees are usually the top performers and are committed, in which they go the extra mile to give their maximum. 
Due to the engagement practices, the absenteeism in the organization decreases, leading to increased retention, which not only reduces the recruitment cost but also ensures that the key people in the organization are retained in the organization, this eventually brings success and improved business performance (Rich et al., 2010).

\section{Conclusion}

Many factors affect organizational performance that managers need to be aware of and have to work on to improve all the time. Literature has shown that various scholars over the years have studied employee engagement in terms of measures, and conditions: such as De Mello et al. (2008) found that engagement is a challenging and a complex goal; and it must be planned for carefully in the long-run. Organizations with friendlycultures attract talented people, respect individual needs, and inspire employees to pursue a common and exciting vision of the future. Engagement is generally improves performance when the conditions are right, when individuals are happy, and when the leaders are focused and inspired; and outcomes such as quality customer services, performance on the individual, unit, and team levels, and cost reduction (Bandura and Lyons, 2014).

Also, researchers called for more research on the enabling factors of applying electronic services (e.g. Masa'deh, et al., 2008, 2013a, 2013b; Karajeh \& Maqableh, 2014; Maqableh \& Karajeh, 2014; Al-Dmour et al., 2015; Almajali \& Maqableh, 2015; Kateb et al., 2015; Maqableh et al., 2015; Kattoua et al., 2016 ; Masa'deh, 2016; Tarhini et al., 2015; 2016, 2017a, 2017b; Almajali \& Al-Dmour, 2016; Almajali et al., 2016; Alenezi et al., 2017; Aldmour et al., 2017; Ammari et al., 2017; Khwaldeh et al., 2017; Mikkawi \& AlLozi, 2017; Obeidat et al., 2017a,b; Yassien \& Mufleh, 2017; Tarhini et al., 2018; AlDmour et al., 2019), hence, future research is vital to examine these enablers as to assist stakeholders on their decisions on reaching high levels of such services, and in turn enhancing human resources practices in an optimal way.

In addition, for the success of any organization, it is essential that the human resources of that organization are treated well and most importantly are satisfied. A satisfied and engaged employee is not only productive but serves to be a great asset for an organization. Organizational performance is not limited to just the financial performance but also includes the market performance, and shareholder returns which can only be ensured if all the components of the organization work together. In order to bring all these components together, the employees play a major role. It is, therefore, necessary to engage and satisfy the employees so that with their commitment they can enhance not only their performance but also the organizational performance.

\section{References}

Abu Jarad, I., Yusof, N., \& Shafiei, M. (2010). The Organizational Performance of Housing Developers in Peninsular Malaysia. International Journal of Housing Markets and Analysis, 3(2), 146-162. 
Ahmad, R., Ing, H., \& Bujang, S. (2014). Relationship between Selected Factors of Job Satisfaction and Job Performance among Workers at Palm Oil Industries. International Review of Management and Business Research Journal, 3(3), 1751-1766.

Albdour, A., \& Altarawneh, I. (2014). Employee Engagement and Organizational Commitment: Evidence from Jordan. International Journal of Business, 19(2), 178-192.

Al-dalahmeh, M., Khalaf, R., \& Obeidat, B. (2018). The Effect of Employee Engagement on Organizational Performance via the Mediating Role of Job Satisfaction: The Case of IT Employees in Jordanian Banking Sector. Modern Applied Science, 12(6), 17-43.

Al-Dmour, R., Al Haj Dawood, E., Al-Dmour, H., \& Masa'deh, R. (2019). The effect of customer lifestyle patterns on the use of mobile banking applications in Jordan. Int. J. Electronic Marketing and Retailing, Forthcoming.

Aldmour, R., Masa'deh, R., \& Obeidat, B. (2017). Factors influencing the adoption and implementation of HRIS applications: Are they similar. International Journal of Business Innovation and Research, 14(2), 139-167.

Al-Dmour, R, Obeidat, B., \& Almajali, D. (2015). The practice of HRIS applications in business organizations in Jordan: An empirical study. 4th Scientific \& Research Conference on New Trends in Business, Management and Social Sciences (COES\&RJTK15/1).

Alenezi, H., Tarhini, A., Alalwan, A., \& Al-Qirim, N. (2017). Factors affecting the adoption of e-government in Kuwait: A qualitative study. Electronic Journal of e-Government, 15(2), 84-102.

Almajali, D., \& Al-Dmour, R. (2016). The role of information technology in motivating students to accept e-learning adoption in universities: A case study in Jordanian universities. Journal of Business \& Management (COES\&RJ-JBM), 4(1), 36-46.

Almajali, D., \& Maqableh, M. (2015). Assessing the digital divide status of the Jordanian telecentre. International Journal of Communications, Network and System Sciences, 8(11), 428-439.

Almajali, D., Masa'deh, R., \& Al-Lozi, M. (2016). Determinants of the actual use of elearning systems: An empirical study on Zarqa University in Jordan. Journal of Social Sciences (COES\&RJ-JSS), 5(2), 172-200.

Amhalhal, A., Anchor, J., \& Dastgir, S. (2015). The Effectiveness of the Use of Multiple Performance Measures: The Influence of Organizational Contingencies. London: Sage.

Ammari, G., Alkurdi, B., \& Alshurideh, M. (2017). Investigating the impact of communication satisfaction on organizational commitment: a practical approach to increase employees' loyalty. International Journal of Marketing Studies, 9(2), 113-133. 
Anitha J. (2014). Determinants of Employee Engagement and their Impact on Employee Performance.International Journal of Productivity and Performance Management, 63(3), 308-323.

Antony, J., \& Bhattacharyya, S. (2010). Measuring Organizational Performance and Organizational Excellence of SMEs-Part 2: An Empirical Study on SMEs in India. Measuring Business Excellence, 14(3), 42-52.

Ariani, D. (2013). The Relationship between Employee Engagement, OrganizationalCitizenship Behavior, and Counterproductive Work Behavior. International Journal of Business Administration, 4(2), 46-56.

Aziri, B. (2011). Job Satisfaction: A Literature Review. Management Research and Practice, 3(4), 77-86.

Bailey, A., Albassami, F., \& Al-Meshal, S. (2016). The Roles of Employee Job Satisfaction and Organizational Commitment in the Internal Marketing-Employee Bank Identification Relationship. International Journal of Bank Marketing, 34(6), 821-840.

Bakker, A., \& Schaufeli, W. (2008). Positive Organizational Behavior: Engaged Employees in Flourishing Organizations. Journal of Organizational Behavior, 29(2), 147-154.

Bakotić, D. (2016). Relationship between Job Satisfaction and Organizational Performance. Economic Research, 29(1), 118-130.

Bandura, R., \& Lyons, P. (2014). Situations-Vacant Fall where Employees are Engaged Involvement Boosts Various Aspects of Organizational Performance. Human Resource Management International Digest, 22(5), 22-25.

Baylor, K. (2010). The Influence of Intrinsic and Extrinsic Job Satisfaction Factors and Affective Commitment on the Intention to Quit for Occupations Characterized by High Voluntary Attrition. Unpublished Doctoral Dissertation.Nova Southeastern University, Florida, USA.

Carton, R. (2004).Measuring Organizational Performance: An Exploratory Study.Unpublished DoctoralThesis, University of Georgia, Athens.

Chien, M. (2004). A Study to Improve Organizational Performance: A View from SHRM. Journal of American Academy of Business, 4(1/2), 289-291.

Crawford, E., Buckman, B., \& Bergeron, J. (2014). The Antecedents and Drivers of Employee Engagement. Employee Engagement in Theory and Practice,2, 57-81.

Dajani, M. (2015). The Impact of Employee Engagement on Job Performance and Organizational Commitment in the Egyptian Banking Sector. Journal of Business and Management Sciences, 3(5), 138-147. 
Darwish, T. (2013). Strategic HRM and Performance: Theory and Practice. Newcastle Upon Tyne: Cambridge Scholars Publishing.

De Mello, C., Wildermuth, S., \& Pauken, P. (2008). A Perfect Match: Decoding Employee Engagement-Part II: Engaging Jobs and Individuals. Industrial and Commercial Training, 40(4), 206-210.

Deeb, A., Alananzeh, O., \& Tarhini, A. (2019). Factors Affecting Job Performance: The Case of Jordanian Hotels Kitchen Staff. International Journal of Public Sector Performance Management.

Ferreira, P., \& de Oliveira, E. (2014). Does Corporate Social Responsibility Impact on Employee Engagement? Journal of Workplace Learning, 26(3/4), 232-247.

Fu, W., \& Deshpande, S. (2013). The Impact of Caring Climate, Job Satisfaction, and Organizational Commitment on Job Performance of Employees in a China's Insurance Company. Journal of Business Ethics, 124, 339-349.

Gavera, C., Ilies, L., \& Stegerean, R. (2011). Determinants of Organizational Performance: The Case of Romania. Management \& Marketing Challenges for the Knowledge Society, 6(2), 285-300.

Griffin, M. (2003). Organizational Performance Model.Retrieved from: http://griffinoc.com/GOC Organizational Performance Model.pdf

Gruman, J., \& Saks, A. (2011). Performance Management and Employee Engagement. Human Resource Management Review, 21(2), 123-136.

Haque, M., Karim, A., Muqtadir, A., \& Anam, S. (2012). Dimensions of Job Satisfaction of Library Professionals: A Qualitative Exploration. InternationalJournal of Business and Social Research, 2(5), 46-62.

Hernaus, T., Bach, M., \& Vuksic, V. (2012). Influence of Strategic Approach to BPM on Financial and Non-Financial Performance. Baltic Journal of Management, 7(4), 376-396.

Herzberg, F. (1966). Work and the Nature of Man. Cleveland: World Publishing Company.

Hogan, S., \& Coote, L. (2014). Organizational Culture, Innovation, and Performance: A Test of Schein's Model. Journal of Business Research, 67(8), 1609-1621.

Hubbard, G. (2009). Measuring Organizational Performance: Beyond the Triple Bottom Line. Business Strategy and the Environment, 18(3), 177-191. 
Kaplan, R., \& Norton, D. (2001).The Strategy-Focused Organization: How Balanced Scorecard Companies Thrive in the New Business Environment. Boston, MA: Harvard Business School Press.

Karajeh, H., \& Maqableh, M. (2014). Security of cloud computing environment. The 23rd IBIMA Conference on Vision 2020: Sustainable Growth, Economic Development, and Global Competitiveness, USA, 2202-2215.

Karanika-Murray, M., Duncan, N., Pontes, H., \& Griffiths, M. (2015). Organizational Identification, Work Engagement, and Job Satisfaction. Journal of Managerial Psychology, 30(8), 1019-1033.

Kateb, M., Swies, R., Obeidat, B., \& Maqableh, M. (2015). An investigation on the critical factors of information system implementation in Jordanian information technology companies. European Journal of Business and Management, 7(36), 11-28.

Kattoua, T., Al-Lozi, M., \& Alrowwad, A. (2016). A review of literature on E-learning systems in higher education. International Journal of Business Management \& Economic Research, 7(5), 754-762.

Khwaldeh, S., Al-Hadid, I., Masa'deh, R., \& Alrowwad, A. (2017). The association between e-services web portals information quality and ICT competence in the Jordanian universities. Asian Social Science, 13(3), 156-169.

Kotane, I. (2012). The Role of The Analysis of Financial and Non-financial Indicators in the Assessment of performance of The Companies. Management Theory and Studies for Rural Business and Infrastructure Development, 34(5), 93-104.

Latif, M., Ahmad, M., Qasim, M., Mushtaq, M., Ferdoos, A., \& Naeem, H. (2013). Impact of Employee's Job Satisfaction on Organizational Performance.European Journal of Business and Management, 5(5), 166-171.

Lee, I. (2008). Relationship between the Use of Information Technology and Performances of Human Resources Management. Unpublished Doctoral Dissertation, Alliant International University, San Diego, CA.

Lovering, C. (2017). Dimensions of Job Satisfaction. Retrieved from: http://smallbusiness.chron.com/dimensions-job-satisfaction-32681.html

Macey, W.,\& Schneider, B. (2008). The Meaning of Employee Engagement. Industrial and Organizational Psychology, 1(1), 3-30.

Maqableh, M., \& Karajeh, H. (2014). Job scheduling for cloud computing using neural networks. Communications and Network, 6(3), 191-200. 
Maqableh, M., Rajab, L., Quteshat, W., Khatib, T., \& Karajeh, H. (2015). The impact of social media networks websites usage on students' academic performance. Communications and Network, 7(4), 159-171.

Masa'deh, R. (2016). The role of knowledge management infrastructure in enhancing job satisfaction at Aqaba five star hotels in Jordan. Communications and Network, 8(4), 219240.

Masa'deh, R., Al-Henzab, J., Tarhini, A., \& Obeidat, B. (2018). The Associations among Market Orientation, Technology Orientation, Entrepreneurial Orientation and Organizational Performance. Benchmarking: An International Journal, 25 (8), 3117-3142.

Masa'deh, R., Gharaibeh, A., Maqableh, M., \& Karajeh, H. (2013a). An empirical study of antecedents and outcomes of knowledge sharing capability in Jordanian telecommunication firms: A structural equation modeling approach. Life Science Journal, 10(4), 2284-2296.

Masa'deh, R., Hunaiti, Z., \& Bani Yaseen, A. (2008). An integrative model linking ITbusiness strategic alignment and firm performance: The mediating role of pursuing innovation and knowledge management strategies. Communications of the International Business Information Management Association (IBIMA) Journal.

Masa'deh, R., Shannak, R., \& Maqableh, M. (2013b). A structural equation modeling approach for determining antecedents and outcomes of students' attitude toward mobile commerce adoption. Life Science Journal, 10(4), 2321-2333.

Mikkawi, B., \& Al-Lozi, M. (2017). The impact of knowledge management infrastructure on academic staff effectiveness: An empirical study at The University of Jordan. Jordan Journal of Business Administration, 13(1), 95-127.

Mirza, S., \& Javed, A. (2013). Determinants of Financial Performance of a Firm: Case of Pakistani Stock Market. Journal of Economics and International Finance, 5(2), 43-52.

Mitchell, H. (2002). Strategic Worth of Human Resources: Driving Organizational Performance. Retrieved from: http://www.exinfm.com/pdffiles/stratworth.pdf

Mone, E., \& London, M. (2010). Employee Engagement through Effective Performance Management: A Practical Guide for Managers.Routledge, New York, NY.

Musgrove, C., Ellinger, A., \& Ellinger, A. (2014). Examining the Influence of Strategic Profit Emphases on Employee Engagement and Service Climate. Journal of Workplace Learning, 26(3/4), 152-171.

Obeidat, B. (2016). The Effect of Strategic Orientation on Organizational Performance: The Mediating Role of Innovation. International Journal of Communications, Network and System Sciences, 9, 478-505. 
Obeidat, B., Hadidi, A., \& Tarhini, A. (2017a). Factors affecting strategy implementation: a case study of pharmaceutical companies in the Middle East. Review of International Business and Strategy, 27(3), 386-408.

Obeidat, B., Tarhini, A., \& Aqqad, N. (2017b). The impact of intellectual capital on innovation via the mediating role of knowledge management: A structural equation modeling approach. International Journal of Knowledge Management Studies, 8(3/4), 273-298.

Obeidat, B., Zyod, D., \& Gharaibeh, A. (2015). The Associations among Transformational Leadership, Transactional Leadership, Knowledge Sharing, Job Performance, and Firm Performance: A Theoretical Model. Journal of Social Sciences (COES\&RJ-JSS), 4, 848-866.

Phillips, D. (2014). Anchoring Talent Management to Business Performance. Journal of Property Management, 17-20.

Prieto, I., \& Revilla, E. (2006). Learning Capability and Business Performance: A NonFinancial and Financial Assessment. The Learning Organization, 13(2), 166-185.

Ramezan, M., Sanjaghi, M., \& Baly, H. (2013). Organizational Change Capacity and Organizational Performance.Journal of Knowledge-Based Innovation in China, 5(3), 188212.

Rich, B., Lepine, J., \& Crawford, E. (2010). Job Engagement: Antecedents and Effects on Job Performance. Academy of Management Journal, 53(3), 617-635.

Schaufeli, W., Schaufeli, A., \& Salanova, M. (2006). The Measurement of Work Engagement with a Short Questionnaire. Educational and Psychological Measurement, 66(4), 701-716.

Shahin, A. Naftchali, J., \& Pool, J. (2014).Developing a Model for the Influence of Perceived Organizational Climate on Organizational Citizenship Behaviour and Organizational Performance based on Balanced Score Card. International Journal of Productivity and Performance Management, 63(3), 290-307.

Shi, M., \& Yu, W. (2013). Supply Chain Management and Financial Performance: Literature Review and Future Directions. International Journal of Operations \&Production Management, 33(10), 1283-1317.

Shmailan, A. (2016). The Relationship between Job Satisfaction, Job Performance and Employee Engagement: An Explorative Study. Issues in Business Management and Economics, 4(1), 1-8.

Spector, P. (1997). Job Satisfaction: Application, Assessment, Causes, and Consequences, (3rd ed.). Thousand Oaks, CA, Sage Publications. 
Taghian, M., D'Souza, C., \& Polonsky, M. (2015), A Stakeholder Approach to Corporate Social Responsibility, Reputation and Business Performance. Social Responsibility Journal, 11(2), 340-363.

Tarhini, A., Alalwan, A., Al-Qirim, N., \& Algharabat, R. (2018). An analysis of the factors influencing the adoption of online shopping. International Journal of Technology Diffusion (IJTD), 9(3), 68-87.

Tarhini, A., Al-Badi, A., Almajali, M., \& Alrabayaah, S. (2017a). Factors influencing employees' intention to use cloud computing. Journal of Management and Strategy, 8(2), 47.

Tarhini, A., Al-Busaidi, K., Bany Mohammed, A., \& Maqableh, M. (2017b). Factors influencing students' adoption of e-learning: A structural equation modeling approach. Journal of International Education in Business, 10(2), 164-182.

Tarhini, A., Bany Mohammed, A., \& Maqableh, M. (2016). Modeling factors affecting student's usage behaviour of e-learning systems in Lebanon. International Journal of Business and Management, 11(2), 299.

Tarhini, A., Mgbemena, C., \& Trab, MSA. (2015). User adoption of online banking in Nigeria: A qualitative study. Journal of Internet Banking and Commerce, 20(3), 1-8.

Tsai, C., \& Yen, Y. (2008). A Model to Explore the Mystery between Organizations \& Downsizing Strategies and Firm Performance: Integrating the Perspectives of Organizational Change, Strategy and Strategic Human Resource Management. Journal of Organizational Change Management, 21(3), 367-384.

Wicker, D. (2011). Job Satisfaction: Fact or Fiction: Are you Satisfied with your Job? Bloomington: AuthorHouse.

Xu, J., \& Cooper Thomas, H. (2011). How can Leaders Achieve High Employee Engagement? Leadership \& Organization Development Journal, 32(4), 399-416.

Yassien, E., \& Mufleh, M. (2017). The impact of ERP system's usability on enterprise resource planning project implementation success via the mediating role of user satisfaction. Journal of Management Research, 9(3), 49-71. 